\title{
Pemerolehan Bahasa Pada Anak Berkebutuhan Khusus
}

\author{
Leni Rahmania ${ }^{a, 1}$, Anggia Suci Pratiwi ${ }^{a, 2}$, dan Rahmat Permana ${ }^{a, 3}$ \\ ${ }^{a}$ Universitas Muhammadiyah Tasikmalaya, Kota Tasikmalaya, Indonesia \\ ${ }^{1}$ leni24rahmania@gmail.com; ${ }^{2}$ anggia@umtas.ac.id; ${ }^{3}$ rahmat.pgsd@umtas.ac.id
}

\begin{tabular}{l} 
Article info \\
\hline Article history: \\
Received: 23-06-2020 \\
Revised : 05-10-2020 \\
Accepted: 10-11-2020
\end{tabular}

Keywords:

child with special education need

language acquisition SDIT Idrisiyyah

\section{A B S T R A C T}

Children's language acquisition is not only influenced by stimulation factors, but also by responding to a set of tools. This study aims to describe the language acquisition of children with special needs in SDIT Idrisiyyah Tamansari, Tasikmalaya City, West Java. Data were collected using observation, interviews, and documentation. The validity test was carried out by expert judgment and triangulation. The results showed that the acquisition of syntactic language through several components, namely: sentences, clauses, phrases, and words. The syntactic acquisition is in the form of being able to say, but there is still an incorrect pronunciation.

Pemerolehan bahasa anak bukan hanya dipengaruhi faktor rangsangan, tetapi juga dengan mengadakan respon pada seperangkat peralatan. Penelitian ini bertujuan untuk mendeskripsikan pemerolehan bahasa anak berkebutuhan khusus di SDIT Idrisiyyah Tamansari, Kota Tasikmalaya Jawa Barat. Data dikumpulkan dengan metode observasi, wawancara, dan dokumentasi. Uji validitas dilakukan dengan expert judgment dan triangulasi. Hasil penelitian menunjukkan bahwa pemerolehan bahasa sintaksis melalui beberapa komponen, yaitu: kalimat, klausa, frasa, dan kata. Pemerolehan sintaksis berupa mampu mengatakan, tetapi masih ada pengucapan yang tidak tepat.

Copyright $\odot 2020$ Institut Agama Islam Negeri Syekh Nurjati Cirebon. All rights reserved.

\section{PENDAHULUAN}

Pemerolehan bahasa anak dipengaruhi oleh faktor internal dan eksternal. Pemerolehan bahasa melalui faktor internal sangat dipengaruhi oleh kesiapan seorang anak di dalam dirinya sendiri (Haliza, Kuntarto, \& Kusmana, 2020). Hal ini terkait kesiapan alam bawah sadar seseorang dalam merangsang insting bahasanya. Adapun faktor eksternal meliputi: lingkungan yang sangat dekat dengan anak itu sendiri, seperti lingkungan keluarga, sekolah, dan masyarakat. Ada dua proses yang terjadi ketika seorang kanak-kanak sedang memperoleh bahasa pertamanya, yaitu proses kompetensi dan proses performansi (Pujaningsih, 2010). Kompetensi adalah proses penguasaan tata bahasa yang berlangsung secara tidak disadari. Proses kompetensi ini menjadi syarat terjadi proses perfomansi yang terdiri atas dua buah proses, yakni proses pemahaman dan proses menghasilkan kalimat-kalimat (Chaer, 2009).

Seorang anak akan memperoleh bahasa pertamanya dalam waktu yang relatif singkat, yakni 2-6 tahun. Hal ini karena anak memperoleh rangsangan atau stimulus lalu merespons (Mulyaningsih, 2015). Sejak lahir, setiap orang dilengkapi innate dengan seperangkat peralatan yang memungkinkannya memperoleh bahasa pertama. Bahasa pertama ini biasa disebut dengan Language 
Acquistion Device (LAD) atau peralatan pemerolehan bahasa (Chomsky dalam Zahrina, 2016). Bahasa bersifat sistematik atau berpola, yaitu sistem bunyi dan sistem makna. Bahasa itu juga manusiawi, maksudnya adalah alat komunikasi yang digunakan oleh manusia. Bahasa dan manusia saling berhubungan hal yang tidak dapat dipisahkan karena keduanya berkembang secara bersama (Anggraeni, Tirtayani, \& Sujana, 2019). Jika tidak pernah belajar berbicara atau berbahasa, anak tidak akan pernah memiliki kemampuan berbicara atau berbahasa (Suhardi, 2013).

Pada usia anak-anak, pemerolehan bahasa meliputi: ucapan yang dihasilkan oleh bunyi-bunyi pilihan kata, bentukan, dan kalimat-kalimat yang dibuat dengan meniru orang dewasa (Pandudinata, Sumarlam, \& Saddhono, 2018). Ada anak yang mengalami gangguan ketika lahir ataupun bawaan gen dari orang tua. Hasil wawancara dengan orang tua yang bernama Syafiq bahwa ketika melahirkan dengan keadaan normal, tetapi permasalahannya adalah pola asuh orang tua. Berdasarkan hasil wawancara dengan ibu Lia Yuliani (Guru Kelas I) menyatakan bahwa anak yang bernama Syafiq didiagnosis autis ringan sesuai hasil tes psikolog. Hal ini terjadi pada anak belum bisa memahami bahasa dan mengucapkan bahasa secara cepat. Anak autis ringan memiliki gangguan dalam berbahasa sehingga penyerapan bahasa anak autis berbeda dengan anak normal (Martina, 2014). Autis ringan masih bisa menunjukkan sedikit respon kepada orang yang mengajak berkomunikasi meskipun hanya terjadi sesekali (Martina, Syam, \& Saman, 2014).

Berdasarkan observasi awal pada anak berkebutuhan khusus yang didiagnosis autis ringan. Childhood Autisme Rating Scale (CARS) membagi autis menjadi tingkatan, yaitu: autis ringan, sedang dan berat. Bahkan dapat dikatakan pemerolehan bahasa pada anak autis ringan ini bersifat lambat dalam sintaksis. Menurut Siegel dalam (Sastra, 2011) anak autis mengalami: 1) masalah atau gangguan di bidang komunikasi, 2) masalah atau gangguan di bidang interaksi sosial, 3) masalah atau gangguan di bidang sensoris, 4) masalah atau gangguan di bidang pola bermain, 5) masalah atau gangguan di bidang perilaku, dan 6) masalah atau gangguan di bidang emosi.

Anak bernama Syafiq ini pemerolehan sintaksis mengalami keterlambatan. Pola komunikasi yang dilakukan oleh Syafiq ini cenderung membeo. Memperoleh sintaksis dari struktur luar yaitu ucapan yang telah didengarnya, lalu ucapan tersebut diintegrasikan dari struktur dalam anak dan membentuk pola sintaksis. Berdasarkan uraian di atas, maka perlu dilakukan suatu penelitian yang bertujuan untuk mengetahui kasus pemerolehan bahasa anak berkebutuhan khusus yang didiagnosis autis ringan dalam pemerolehan sintaksis.

Kementerian Pemberdayaan Perempuan dan Perlindungan Anak Republik Indonesia 2013 dalam (Ratri, 2016) menjelaskan bahwa anak berkebutuhan khusus adalah: Anak yang mengalami keterbatasan atau keluarbiasaan, baik fisik, mental-intelektual, sosial, maupun emosional, yang berpengaruh secara signifikan dalam proses pertumbuhan atau perkembangannya dibandingkan dengan anakanak lain yang sesuai dengannya. Terdapat penelitian yang memiliki relevansi dalam penelitian ini yaitu pada artikel jurnal yang berjudul Pemerolehan Sintaksis Pada Anak Autisme (Zahrina, 2016) merupakan penelitian deskriptif kualitatif. Sumber data yang diperoleh berdasarkan wawancara terhadap orang tua, guru dan pengamatan terhadap objek penelitian. Hasil dari penelitian ini bahwa pemerolehan sintaksis pada anak autis mengalami keterlambatan. Anak 
penyandang autis memperoleh sintaksis dari struktur luar yaitu ucapan yang didengarnya, lalu ucapan tersebut diintegrasikan dari struktur dalam anak membentuk pola sintaksis dan anak memahami makna dari ucapan dalam berkomunikasi.

\section{METODE}

Lokasi penelitian merupakan tempat penelitian berlangsung. Penelitian ini dilaksanakan di Sekolah Dasar Islam Terpadu (SDIT) Idrisiyyah Tamansari RT 001 RW 011 Kelurahan Mulyasari Kecamatan Tamansari Kota Tasikmalaya. Penelitian ini dilaksanakan pada Rabu 05 Februari tahun 2020. Jenis penelitian ini menggunakan pendekatan deskriptif kualitatif. Penelitian kualitatif adalah penelitian yang dimaksud untuk memahami fenomena tentang apa yang dialami dalam bentuk kata-kata dan bahasa, pada suatu konteks khusus yang alamiah dan dengan memanfaatkan berbagai metode alamiah (Moleong, 2007).

Penelitian ini dilakukan dengan cara mengamati secara langsung anak yang menjadi subjek penelitian. Penelitian ini menggunakan teknik pengumpulan data melalui observasi, wawancara dan dokumentasi. Data pemerolehan bahasa yang telah diucapkan selanjutnya disimak. Data diambil dengan ikut berinteraksi dan mendorong subjek penelitian untuk pemerolehan bahasa. Data dikumpulkan dengan cara mengamati dan memahami pemerolehan bahasa anak berkebutuhan khusus. Hasil rekaman kemudian dituangkan pada verbatim yaitu secara tulisan dan diamati melalui kartu data. Penelitian ini dilakukan selama 30 hari.

Teknik analisis data dalam penelitian ini terdiri atas tiga tahap, yaitu Pertama, reduksi. Reduksi dilakukan dengan cara melakukan proses transkripsi tuturan dalam tulisan, data yang telah ditranskripsikan kemudian di identifikasi, melakukan proses pengklasifikasian, dan pemaknaan data sebelumnya yang sudah diklasifikasikan. Kedua, tahap penyajian. Pada tahap penyajian ini data yang telah diklasifikasikan disajikan dalam bentuk tabel. Ketiga, tahap penarikan kesimpulan. Dalam tahap ketiga ini dilakukan proses verifikasi ulang terhadap data awal yang sudah dikumpulkan. (Sugiyono, 2016).

Validitas data diperoleh dari validitas kartu data (expert Judgment) yang dilakukan oleh Anggia Suci Pratiwi, M. Pd. sebagai dosen pengampu mata kuliah Bahasa dan Sastra Indonesia program studi pendidikan guru sekolah dasar (PGSD) Universitas Muhammadiyah Tasikmalaya. Berikut validitas kartu data (expert judgment) yaitu dengan kartu data pada tabel yang berisi waktu, kode data terdapat angka romawi I (Pemerolehan kalimat), II (Pemerolehan klausa), III (Pemerolehan frasa), IV (Pemerolehan kata). Validitas data penelitian ini juga menggunakan pada triangulasi yaitu teknik pemeriksaan keabsahan data dengan melakukan pengecekan atau perbandingan terhadap data yang diperoleh dengan sumber, dan menggunakan bahan referensi yaitu alat pendukung untuk membuktikan data yang ditemukan. (Sugiyono, 2014).

\section{HASIL DAN PEMBAHASAN}

Noam Chomsky, yang seorang linguis 'penemu' teori tata bahasa generatif transformasi itu, berkeyakinan bahwa dalam diri anak terdapat semacam "alat" yang dipergunakan sebagai sarana memperoleh bahasa. Sejak dilahirkan anak sudah memiliki pembawaan, bakat (innate capacity), yang berupa Languange Acquisition (LAD, alat pemerolehan bahasa) untuk memperoleh bahasa secara alami. (Dardjowidjodjo, 2012) Adanya innate capacity atau LAD tersebut 
menurut Chomsky dalam (Nurgiyantoro, 2005) dapat dipergunakan untuk menerangkan apa yang terjadi di dalam diri anak yang secara ajaib dapat belajar bahasa secara cepat.

Pemerolehan bahasa pada Syafiq hanya mengukur saja pada pemerolehan sintaksis. Sintaksis telaah mengenai pola-pola yang dipergunakan sebagai sarana untuk menggabung-gabungkan kata menjadi kalimat (Kumalasari et al., 2018). Ada pula yang mengatakan bahwa sintaksis adalah bagian atau cabang dari ilmu bahasa yang membicarakan seluk beluk wacana, kalimat klausa, dan frasa. (Ramlan, 2005). Dalam bidang sintaksis anak memulai berbahasa dengan mengucapkan satu kata (atau bagian kata) (Dardjowidjodjo, 2018). Kata ini bagi anak, sebenarnya kalimat penuh, tetapi karena dia belum dapat mengatakan lebih dari satu kata, dia hanya mengambil satu kata dari seluruh kalimat itu.

Subjek dalam penelitian ini adalah Muhammad Syafiq. Subjek penelitian anak berkebutuhan khusus kelas I yang didiagnosis autis ringan, dengan karakteristik khusus yang berbeda dengan anak pada umumnya (Ratri, 2016). Pemerolehan bahasa yang diteliti adalah sintaksis. Sintaksis merupakan salah satu cabang linguistik yang mempelajari kata dalam hubungannya dengan kata lain untuk membentuk kalimat, klausa, frasa dan kata sebagai satuan ujaran (Ramlan, 2005).

Proses observasi menggunakan panduan observasi agar fakta lapangan yang diperoleh berkaitan dengan penelitian Pemerolehan Bahasa Anak Berkebutuhan Khusus. Pengumpulan data dilakukan dengan teknik wawancara, menggunakan panduan wawancara yang berisi pertanyaan secara garis besar yang akan ditanyakan. Wawancara dilakukan secara mendalam dan berulang-ulang agar data yang akan dikumpulkan lebih jelas dan lengkap. Berikut ini disajikan deskripsi hasil penelitian yang telah dilakukan.

\section{Deskripsi data hasil penelitian tentang pemerolehan bahasa anak berkebutuhan khusus kelas I di SDIT Idrisiyyah Tamansari}

Berdasarkan observasi didapat hasil data yang memperkuat dalam pemerolehan bahasa anak berkebutuhan khusus di SDIT Idrisiyyah Tamansari. Observasi difokuskan pada aspek sintaksis yang terdiri dari kalimat, klausa, frasa, dan kata. Hasil observasi pada pemerolehan bahasa ABK ini sebagai pencarian data pemerolehan bahasa dalam melakukan komunikasi di kelas dan di lingkungan sekolah.

Kemampuan verba Syafiq ini sudah jelas melakukan komunikasi, tetapi ketika dikaitkan dengan pemerolehan bahasa pada sintaksis tidak sesuai karena dalam penyampaian kalimatnya apa yang ada dalam pikirannya. Kemampuan mendengar Syafiq tidak mengalami gangguan dan mampu memberikan respon kepada orang yang bertanya tapi jawabannya sering tidak nyambung.

Hasil observasi pada pemerolehan bahasa ABK yang difokuskan kepada Syafiq dalam melakukan komunikasi di lingkungan sekolah masih susah untuk dipahami apa yang diucapkannya, bagi orang-orang yang baru mengenalnya. Saat ngobrol dengan orang yang tidak dikenal maka Syafiq kurang merespon tapi jika dengan orang yang dikenali akan merespon tapi tidaklah nyambung apa yang telah ditanyakannya. Adapun hasil observasi komunikasi dengan Syafiq seperti bertanya "mau ngapain pulang?" Kemudian Syafiq menjawab "Nissa Sabyan".

Berdasarkan wawancara dengan Syafiq, dapat diketahui bahwa mengenai pemerolehan bahasa ABK berbeda dengan anak normal. Perbedaan pola komunikasi anak $\mathrm{ABK}$ yang bersanding autis cenderung menghindari 
berkomunikasi dan akan mengalami keterlambatan dalam merespon. Pemerolehan bahasa pada penderita $\mathrm{ABK}$ yang bersanding autis biasanya sering melakukan apa yang telah ia pahami, lihat, dirasakan, dan tidak memaksakan pada hal-hal yang ia tidak sukai. Ketika melakukan percakapan kepada Syafiq seringlah mengalami tidak nyambung apabila orang yang mengajak ngobrolnya itu tidak mengetahui apa yang ia sukai atau apa yang ia sudah lihat secara nyata.

Berdasarkan pada hasil wawancara dengan guru kelas ditemukan bahwa pemerolehan bahasa yang dilakukan oleh Syafiq ini masih belum mampu berbicara dua arah yang berarti tidak nyambung dan tidak dapat dipahami oleh orang lain. Saat berkomunikasi dengan temannya Syafiq sering menghindar karena oleh temannya melakukan komunikasi sedangkan apa yang diucapkan oleh temannya tidak paham oleh Syafiq sendiri sebab tidak terlihat secara langsung atau telah di dengar olehnya.

Pemerolehan bahasa Syafiq ini dalam perbendaharaan kosakatanya banyak keluar dari apa yang sudah dilihat dari televisi dan youtube. Sehingga pemerolehan bahasa di dalam memorinya banyak bahasa yang sedikit orang lihat terutama bagi anak di usia dini, seperti dalam berita, iklan, dan film kartun. Proses kegiatan belajar mengajar di kelas Syafiq jarang masuk kelas biasanya suka di ruangan tata usaha karena di dalam kelas banyak orang yang belum kenal. Apabila berada di dalam kelas sering melakukan jalan-jalan di kelas dan membeo meskipun teman-temannya sedang melakukan pembelajaran. Kegiatan pembelajaran ini pasti dilakukan dengan cara berkomunikasi, khususnya bagi anak berkebutuhan khusus yang bersanding anak autis ini memiliki perbedaan dengan anak normal.

Berdasarkan pada hasil wawancara dengan orang tua bahwa pola asuh orang tua yang diberikan kepada Syafiq terdapat kekeliruan. Anak sejak dini adalah masa emas dimana anak tumbuh kembang. Awal pola asuh yang sudah keliru dari kecil sudah dikenalkan dengan menonton film jadi pemerolehan bahasa yang di dapat oleh Syafiq itu dari film bukanlah dari orang tua secara langsung.

Pemerolehan bahasa pada Syafiq terlihat sangat berbeda, maka orang tua Syafiq melakukan tes psikotes, hasilnya bahwa didiagnosis autis ringan. Autis ringan ini masih bisa diubah dengan pola asuh orang tua dengan menguranginya menonton film di youtube dan merubah filmya dengan kegiatan yang dilakukan oleh manusia bukanlah kartun. Kegiatan yang diterapkan oleh orang tua syafiq melakukan kegiatan seperti membantu memasak tempe. Perkembangan bahasa ketika di rumah cukup baik, karena orang yang berada di rumah sering bertemu. Syafiq sering melakukan berbicara sendiri seperti membeo.

Berdasarkan pada hasil dokumentasi saat penelitian ditentukan data mengenai pemerolehan bahasa pada anak berkebutuhan khusus dalam melakukan komunikasi mampu menjawab apabila orang tersebut sudah kenal. Pemerolehan Bahasa syafiq di lingkungan sekolah dengan temannya terutama pada sintaksis masih kurang jelas. Ketika Syafiq ditanya mengenai suatu hal jawabannya tidak relevan dengan pertanyaan.

Hasil dokumentasi yang di dapat adalah berdasarkan pada rekaman kegiatan di kelas maupun di luar kelas selama melakukan komunikasi. Dokumen bentuk rekaman ini dituangkan dalam catatan yang disebut verbatim. Rekaman tersebut bisa menemukan pemerolehan bahasa Syafiq dalam sintaksis yang meliputi kalimat tunggal, kalimat majemuk, frasa, dan kata. 
Berdasarkan hasil observasi dan wawancara yang dilakukan mengenai pemerolehan bahasa pada aspek sintaksis yang meliputi kalimat tunggal, kalimat majemuk, klausa, dan frasa diperoleh pada komunikasi yang dilakukan oleh Syafiq.

\section{a. Pemerolehan Bahasa Sintaksis}

Data hasil penelitian yang telah dideskripsikan di atas akan dipaparkan terkait hasil penelitian secara keseluruhan yang akan diambil dari analisis data untuk mengetahui pemerolehan bahasa anak berkebutuhan khusus kelas I di SDIT Idrisiyyah Tamansari yang memperoleh sintaksis dari ucapan dalam berkomunikasi. Namun ketika berbahasa anak cenderung membeo dan ketika melakukan komunikasi dengan orang lain bahasanya tidak jelas.

Pemerolehan bahasa anak berkebutuhan khusus pada Syafiq ini fokus pada komponen sintaksis yang meliputi pada kalimat tunggal, kalimat majemuk, klausa, frasa, dan kata maka diperoleh pembahasan sebagai berikut.

\section{1) Pemerolehan Kalimat}

Kalimat adalah satuan gramatik oleh adanya jeda panjang yang disertai nada akhir turun dan naik. Pemerolehan kalimat pada penelitian ini dilihat pada kalimat tunggal dan kalimat majemuk. Kalimat tunggal adalah kalimat yang hanya terdiri dari satu klausa. Kalimat tunggal Syafiq mampu berujar seperti pada percakapan di bawah ini:

G : "Syafiq sakit?"

$\mathrm{S}$ : "Tidak TPI Banjar"

G : " Kenapa TPI Banjar?"

S : “.......... Kita mau Idrisiyyah dan akan untuk dalam saya ingin Kabupaten Kota Tasikmalaya yang .......... bangunan Masjid Jawa Barat.......... kita untuk ............ Untuk masyarakat.......... Shalat Ashar ............. Kabupaten Provinsi Jawa Barat ........... atas untuk .......... oleh ini hari ini kita akan pembangunan ............ TPI Provinsi Jawa Barat .............. untuk pekerja kalau untuk Provinsi Jawa Barat ........ untuk Kabupaten Anda, Kabupaten Pangandaran Pantai........ Masjid Agung......"

Pada percakapan di atas (004) terlihat ketika Syafiq berkomunikasi. Adapun pemerolehan kalimat tunggal pada Syafiq sebagai berikut.

(004a)

$(004 c)$

$$
\begin{array}{ll}
\multicolumn{3}{c}{\text { Kita mau Idrisiyyah }} \\
\hline \text { S }
\end{array}
$$

\section{\begin{tabular}{l} 
Kita akan pembangunan \\
\hline S P O
\end{tabular}}

Kalimat di atas sudah tampak kata pada subjek, keterangan dan objek, tetapi masih belum jelas. Hal ini menunjukkan bahwa Syafiq kurang percaya diri. Hal ini seperti yang disampaikan Daroni (2018). Pada kata Idrisiyyah dan Kota Tasikmalaya masih bisa dikatakan secara luas seperti kalimat di bawah ini. (004a) 


\section{Kita mau ke Sekolah Idrisiyyah}

\begin{tabular}{lll}
\hline $\mathrm{S}$ & $\mathrm{O}$
\end{tabular}

(004c)

$$
\begin{aligned}
& \text { Saya ingin pergi Kota Tasikmalaya } \\
& \mathrm{S} \quad \mathrm{P}
\end{aligned}
$$

G : "Syafiq pernah ke Aceh belum?"

$\mathrm{S}$ : “......... Kami-kami ada di rumah"

Percakapan di atas dalam pemerolehan kalimat tunggal Syafiq, jika diuraikan pada pola kalimat tunggal sebagai berikut.

$$
\frac{\text { Kami - kami ada di rumah }}{\mathrm{S} \quad \mathrm{P} \quad \mathrm{K}}
$$

Terdapat verba yang diulang pada subjek. Verba tersebut jika tidak diulang sudah jelas artinya untuk orang banyak seperti kalimat. (005)

$$
\frac{\text { Kami ada di dalam rumah }}{\mathrm{S} \quad \mathrm{P}}
$$

Menunjukkan bahwa ada orang yang lebih dari dua sedang berada di dalam rumah yang sudah jelas terdapat subjek, predikat dan keterangan. (008).

S : "Ada belanja untuk keluarga ada di Kota Tasikmalaya yang

Berdasarkan kalimat yang telah diucapkan pada Syafiq, jika diuraikan pada pola-pola kalimat tunggal sebagai berikut. (008)

$$
\begin{array}{ccc}
\multicolumn{4}{c}{\text { Keluargaku ada di Kota Tasikmalaya }} \\
\hline \text { S } & \text { P } & 0
\end{array}
$$

Kalimat yang diucapkan oleh Syafiq sudah benar terdapat subjek, predikat dan objek. Kalimat tersebut dapat dipahami bagi orang yang mendengarnya. Syafiq sering memakai kata ada daripada sedang, meskipun Syafiq sudah dapat memakainya dengan benar. Masih ada tipe kalimat yang salah seperti kalimah.

$$
\begin{aligned}
& \text { G : "Syafiq tadi makan sama apa?" } \\
& \text { S : "Saya sama makan naget" }
\end{aligned}
$$

Dalam percakapan tersebut, guru menanyakan kepada Syafiq akan tetapi jawabannya masih belum dapat dipahami oleh penanya. Adapun jika diuraikan pola-pola kalimat tunggal sebagai berikut.

$$
\begin{array}{ll}
\multicolumn{2}{l}{\text { Saya sama makan naget }} \\
\mathrm{S} \quad \mathrm{P}
\end{array}
$$


Menunjukkan dalam pengucapan bahasa syafiq sering mengucap kata dengan terbalik sehingga tidak dapat dipahami oleh orang lain sebagai lawan bicaranya. Maka kalimat seperti di bawah ini.

$$
\frac{\text { Saya makan sama naget }}{\mathrm{S} \quad \mathrm{P} \quad \mathrm{K}}
$$

Menunjukkan kalimat tunggal yang baik, sehingga lawan bicaranya tidak akan bingung meskipun urutan pada kalimat majemuk sudah jelas.

(018a)

G : "Gimana kata al-akh Trias?"

$\mathrm{S}$ : "Afiq main, naik mobil"

Percakapan di atas menyatakan guru bertanya kepada Syafiq tetapi jawabannya tidak sesuai dengan pertanyaan. Adapun pola-pola kalimat sebagai berikut.

(018a)

\section{\begin{tabular}{ll} 
Afiq main naik mobil \\
\hline $\mathrm{S} \quad \mathrm{P} \quad \mathrm{K}$
\end{tabular}}

Pada kata kerja "main" tidak terdapat kata imbuhan "ber-" menjadi "bermain" kalimat tersebut juga terdapat subjek, predikat dan keterangan. (018b)

\section{Saya sedang di kelas \\ $\begin{array}{lll}S & P & 0\end{array}$}

Sesekali Syafiq menyebutkan dirinya menggunakan kata ganti subjek seperti "saya". Kalimat di atas sudah benar, karena pada kalimat di atas terdapat subjek, predikat dan objek.

(020)

G : "Iya pergi kemana? Jalannya pengen kemana?"

$\mathrm{S}$ : "Afiq pergi ke Tasik"

$\mathrm{G}$ : "Lihat apa?"

$\mathrm{S}$ : "Tasikmalaya"

$\mathrm{G}$ : "Iya lihat apa?"

$\mathrm{S}$ : "Afiq mau lihat wisata kuliner"

$\mathrm{G}$ : "Terus apalagi?"

$\mathrm{S}$ : "Euuuu cari makam"

G : "Cari makanan?"

S : "Bukan, makam. Afiq lalu pergi ke makam"

Percakapan di atas guru sedang melakukan komunikasi dengan Syafiq mengenai rencana kegiatan ketika libur sekolah. Adapun pola-pola pemerolehan kalimat tunggal pada Syafiq sebagai berikut.

(020a)

\begin{tabular}{lll} 
Afiq pergi ke Tasik \\
\hline S P O
\end{tabular} 
(020b)

$$
\frac{\text { Afiq mau lihat wisata kuliner }}{\mathrm{S}}
$$

\section{Afiq ada di Masjid Agung Kota Tasikmalaya

$\begin{array}{llll}S & P & 0 & K\end{array}$

(019d)

Afiq lalu pergi ke makam

Menunjukkan kalimat yang tepat. Kata tunggal di atas menunjukkan kata subjek, predikat dan objek yang benar. Sehingga mudah dipahami oleh lawan bicara. Berdasarkan perkembangan kalimat tunggal yang terjadi pada Syafiq sehingga Syafiq berusaha untuk mengutarakan keinginannya melalui bahasa yang diucapkannya.

Kalimat majemuk adalah kalimat yang terdiri dari dua klausa atau lebih. Dalam hal ini, berkenaan dengan sifat atau hubungan klausa-klausa di dalam kalimat itu, dibedakan adanya kalimat majemuk koordinatif (kalimat majemuk setara), kalimat majemuk subordinatif (kalimat majemuk bertingkat), dan kalimat majemuk kompleks (kalimat majemuk campuran) (Awalludin, 2017).

Adapun pemerolehan bahasa kalimat majemuk yang telah diucapkan oleh Syafiq diantaranya kalimat seperti:

(007)

G : "Syafiq berenangnya sama siapa?"

$\mathrm{S}$ : "Afiq pergi dengan Ibu Sabyan berenang"

Berdasarkan percakapan tersebut pada kalimat majemuk guru bertanya kepada Syafiq dan jawabannya dapat dipahami. Adapun pola-pola kalimat majemuk pada Syafiq sebagai berikut.

(007)

Afiq pergi dengan Ibu Sabyan berenang

\begin{tabular}{llll}
\hline S1 & P & S2 & K
\end{tabular}

(026)

$\mathrm{G}$ : "Iya, sekarang mau pergi kemana?"

(026)

$\mathrm{S}$ : "Afiq main dan teman ke warung"

\begin{tabular}{ccc}
\multicolumn{4}{c}{ Afiq main dan teman ke warung } \\
\hline S1 & P & S2
\end{tabular}

Kalimat majemuk yang diucapkan oleh Syafiq (007) memakai koordinatif yaitu kata "dengan" sedangkan kalimat (026) memakai kalimat majemuk koordinatif dengan koordinator "dan" dengan menggunakan kata imbuhan "ber" pada kata "main" sehingga kata majemuk yang telah diucapkan oleh Syafiq lebih mudah dipahami oleh lawan bicara.

(020)

G : "Makam dimana?"

$\mathrm{S}$ : "Di makam Eyang gabudi.... Syafiq pergi ke makam eyang nanti Lebaran" 


\section{Indonesian Language Education and Literature \\ e-ISSN: 2502-2261 \\ http://www.syekhnurjati.ac.id/jurnal/index.php/jeill/ \\ Vol. 6, No. 1, Desember 2020, 104 - 118}

(020)

\section{Syafiq pergi ke makam eyang nanti lebaran

$\begin{array}{lllll}\text { S1 } & \mathrm{P} & \mathrm{K} 2 & \mathrm{~S} 2 & \mathrm{~K} 2\end{array}$

Menunjukkan kata majemuk, yang tidak mempunyai koordinatif dan subordinatif pada kalimat (020).

(027)

G : "Bukunya udah di baca sama Afiq?"

S : "Afiq kan lagi baca sama Pak Ustadz dank ke perpustakaan sekolah"

Berdasarkan percakapan tersebut, bahwa Syafiq suka membaca buku dengan Pak Ustad. Adapun pola pada kalimat majemuk sebagai berikut:

(027)

\begin{tabular}{cccc} 
Syafiq sedang baca sama Pa Ustad dan ke perpustakaan \\
\hline S1
\end{tabular}

Kalimat majemuk yang diucapkan oleh Syafiq (027) memakai koordinatif yaitu kata "dan" tetapi kalimat yang telah diucapkan oleh Syafiq masih belum mampu menempatkan pada kalimat majemuk dengan tepat. Dengan menambahkan kata imbuhan "me-“" pada kata "baca" menjadi "membaca" dengan mengefektifkan ucapan.

$\frac{\text { Syafiq dan Pak Ustadz sedang membaca buku di perpustakaan }}{\text { S1 }}$

Pada dasarnya Syafiq sudah mampu mengucapkan kalimat majemuk dengan koordinatif "dan", "dengan", pada setiap perkataan yang diucapkan. Namun, Syafiq belum mampu menempatkan konjungsi koordinatif dan konjungsi subordinatif pada kalimat majemuk yang diucapkannya.

\section{2) Pemerolehan Klausa}

Menurut Ramlan (2005) Klausa ialah satuan gramatik yang terdiri dari S, P baik disertai objek (O), pelengkap (Pel), dan keterangan (KET) ataupun tidak. Klausa adalah satuan gramatikal yang setidak-tidaknya terdiri atas subjek dan predikat. Pemerolehan klausa yang telah dikuasai oleh Syafiq seperti terlihat pada klausa berikut:

(002b) Afiq pulang

Klausa yang diucapkan oleh Syafiq pada klausa di atas berkategori verba yaitu pada kata pulang. Kata pulang ni yang berarti kata kerja diserta dengan subjek yaitu pada kata Afiq.

(005) ni Ayah

(010) ibu guru

Pada klausa tersebut klausa yang predikatnya berupa nomina, karena nomina yang berarti untuk menunjukkan kata orang pada (005) Ayah.

(002a) Jangan berisik

Klausa yang diucapkan oleh Syafiq sama hanya dengan klausa nomina, mengharuskan predikat berupa kategori verba, klausa di atas tersebut menunjukkan menekankan pada kata jangan yang berarti bahwa yang telah diucapkan oleh Syafiq tersebut menunjukan itu tidak harus dilakukan, dan kata berisik itu yang termasuk verba. 
(008) sekitar ada dua puluh di kecamatan

(011) baca dunia empat

Klausa di atas adalah kata yang dapat diikuti oleh kata penyukat. Seperti di atas kata empat yang memiliki distribusi yang sama dengan kata bilangan.

\section{3) Pemerolehan Frasa}

Istilah frasa (phrase) digunakan sebagai satuan sintaksis yang satu tingkat berada di bawah satuan klausa, atau satu tingkat berada di atas satuan kata. Frasa ialah satuan gramatik yang terdiri dari dua kata atau lebih yang tidak melampaui batas fungsi unsur klausa (Ramlan, 2005).

Klasifikasi frasa dapat dibedakan berdasarkan sifatnya dan persamaan distribusi. Berdasarkan sifatnya, frasa dapat dibedakan menjadi dua jenis, yaitu frasa endosentrik dan frasa eksosentrik dan persamaan distribusi kelas kata yaitu frasa nominal, frasa verbal, frasa adjektiva, frasa numeral, frasa proposional, dan frasa pronominal.

Dalam perkataan yang diungkapkan oleh Syafiq muncullah frasa-frasa seperti di bawah ini.

(001) Anak Sholeh

(006e) Sembilan ratus

Frasa di atas menunjukkan kata frasa endosentrik koordinatif yang memiliki unsur-unsur setara atau sederajat. Kesetaraannya itu dapat dibuktikan oleh kemungkinan unsur-unsur di atas dapat dihubungkan dengan kata penghubung dan atau atau. Misalnya kata yang diungkapkan oleh Syafiq yang terdapat pada nomor (001) dapat dihubungkan dengan kata penghubung dan menjadi "anak dan sholeh".

(003) Sot Subuh

(004) Salat Ashar

Kata yang diucapkan oleh Syafiq di atas menunjukkan frasa endosentrik yang atributif dengan unsur-unsur yang tidak setara. Oleh karena itu, unsurunsurnya tidak mungkin dapat dihubungkan oleh kata sambung dan atau atau. Namun, ucapan Syafiq pada nomor (003) terdapat kata "Sot" yang dapat diperbaiki menjadi "Sholat" sehingga dapat disempurnakan menjadi "Sholat Subuh".

(002a) Di Tasik

Menunjukkan Frasa Eksosentrik Direktif Syafiq sering tampak saat berbicara dengan komponen pertamanya berupa proposisi di. Namun, ada beberapa frasa yang harus diperbaiki untuk dapat dimengerti oleh pendengar.

(008c) yang ada di Situ Gede

(011a) yang itu Provinsi

Data 008c menunjukkan frasa eksosentrik nondirektif dengan komponen pertamanya berupa artikulus yang sering tampak pada percakapan Syafiq.

Berdasarkan persamaan distribusi dengan kategori atau kelas kata pada pemerolehan oleh Syafiq muncullah frasa-frasa seperti kalimat. Adapun frasa berdasarkan persamaan distribusi dengan kategori atau kelas kata seperti (006a) jid

Frasa jid yang diucapkan oleh Syafiq terdapat kekeliruan kata tersebut tidak dapat di pahami oleh lawan bicara. Adapun maksud yang diucapkan oleh Syafiq itu adalah masjid. Frasa masjid termasuk golongan frasa nominal karena frasa ini mempunyai distribusi yang sama dengan nominal atau kata benda. 
(006f) Dua diskon

Data 006f menunjukkan kata dua dalam frasa tersebut termasuk golongan kata bilangan. Kata di atas termasuk golongan kata penyukat. Jadi, frasa numeral tersebut terdiri dari unsur kata bilangan diikuti kata penyukat.

\section{4) Pemerolehan Kata}

Kata berdasarkan kelasnya atau perilaku sintaksisnya, kata dibagi menjadi lima macam, yaitu verba (kata kerja), adjektiva (kata sifat), adverbia (kata keterangan), nomina (kata benda), dan kata tugas (yang hanya memiliki arti gramatikal dan tidak memiliki arti leksikal). Adapun kata yang membedakan seperti pada kata berikut.

Tabel 1. Pemerolehan Kata Verba

\begin{tabular}{llll}
\hline Kode & Kata & Kode & Kata \\
\hline$(002 \mathrm{~d})$ & Pulang & $(014 \mathrm{a})$ & Belanja \\
$(002 \mathrm{f})$ & Pulang & $(014 \mathrm{~b})$ & Tidur \\
$(002 \mathrm{~h})$ & Renang & $(017)$ & Baca \\
$(006 \mathrm{a})$ & Belanja & $(020 \mathrm{a})$ & Pergi \\
$(006 \mathrm{~b})$ & Baca & $(027 \mathrm{c})$ & Baca \\
$(007 \mathrm{~b})$ & Pergi & $(029 \mathrm{f})$ & Lari \\
$(007 \mathrm{c})$ & Berenang & $(029 \mathrm{~g})$ & Belajal \\
$(008 \mathrm{~b})$ & Belanja & $(029 \mathrm{~h})$ & Olahraga \\
$(011 \mathrm{a})$ & Baca & & \\
\hline
\end{tabular}

Kata di atas mengandung verba yang memiliki fungsi utama sebagai predikat atau sebagai inti predikat dalam kalimat walaupun dapat juga sebagai fungsi lain seperti pada (002d) pulang menunjukkan bahwa kata tersebut pada kata kerja yang dilakukan dan dapat pula diartikan dengan yang lain seperti "heuh kan Afiq pulang”.

Tabel 2. Pemerolehan Kata Verba makna perbuatan

\begin{tabular}{llll}
\hline Kode & Kata & Kode & Kata \\
\hline$(008 \mathrm{~d})$ & Sarapan & $(015 \mathrm{~b})$ & Membayar \\
$(009 \mathrm{c})$ & Sarapan & $(021 \mathrm{a})$ & Makan \\
$(013)$ & Liburan & $(027 \mathrm{~b})$ & Buku \\
$(015 \mathrm{a})$ & Minum & $(028 \mathrm{~b})$ & Duduk \\
\hline
\end{tabular}

Kata di atas menunjukkan makna perbuatan atau aksi, proses, atau keadaan yang bukan sifat atau kualitas. Verba di atas dapat menjawab pertanyaanpertanyaan, seperti: apa yang dilakukan oleh subjek, apa yang terjadi pada subjek, dan verba keadaan yang tidak dapat ditambahkan prefiks ter- yang berarti paling.

(001a) Sholeh

(028a) Baik

Kata di atas termasuk pada adjektiva yang berfungsi sebagai atributif yang memberikan keterangan terhadap nomina seperti yang telah diucapkan oleh Syafiq pada kata sholeh.

(002e) Berisik

(021b) Senang

(029i) Senang 
Kata di atas menunjukkan adjektiva mempunyai fungsi sebagai atribut yang memberikan keterangan terhadap nomina seperti pada (021b) Senang

Tabel 3. Pemerolehan Kata Nomina

\begin{tabular}{llll}
\hline Kode & Kata & Kode & Kata \\
\hline$(002 \mathrm{c})$ & Al-akh & $(027 \mathrm{a})$ & Bu guru \\
$(005 \mathrm{a})$ & Ayah & $(27 \mathrm{~d})$ & Pak Ustad \\
$(010)$ & Ibu guru & $(029 \mathrm{~b})$ & Al Akh \\
$(018 \mathrm{a})$ & Al akh & $(029 \mathrm{~d})$ & Ibu \\
$(018 \mathrm{~b})$ & Teman-teman & & \\
\hline
\end{tabular}

Data menunjukkan kata tersebut yang diucapkan oleh Syafiq di atas termasuk nomina (kata ganti) dimana kata tersebut dipakai untuk mengacu pada nomina lain. Contoh kata pada (010) Ibu Guru dapat diacu dengan pronomina dia atau ia. Bentuknya pada Ibu Guru mengacu kepada Guru.

Tabel 4. Pemerolehan Kata Nomina Pada Manusia

\begin{tabular}{llll}
\hline Kode & Kata & Kode & Kata \\
\hline$(005 \mathrm{e})$ & Ustad Ahmad & $(015 \mathrm{~d})$ & Syekh Muhammad \\
$(008 \mathrm{a})$ & Syekh Muhammad Fathurrahman & $(015 \mathrm{e})$ & Abdul Fattah \\
\hline
\end{tabular}

Kata di atas menunjukan nomina semantik, berarti kata tersebut mengacu padu manusia.

(004c) Pekerja

(012c) Pendidikan

(012d) Masyarakat

Kata di atas menunjukkan bahwa yang predikatnya verba, dimana nomina cenderung menduduki fungsi subjek, objek, atau pelengkap.

Tabel 5. Pemerolehan Kata Nomina Benda

\begin{tabular}{llll}
\hline Kode & Kata & Kode & Kata \\
\hline$(002 \mathrm{~b})$ & Pohon & $(009 \mathrm{~b})$ & Buku \\
$(002 \mathrm{~g})$ & Sekolah & $(011 \mathrm{~b})$ & Masjid \\
$(004 \mathrm{~b})$ & Masjid & $(012 \mathrm{a})$ & Sekolah \\
$(005 \mathrm{~b})$ & Rumah & $(012 \mathrm{~b})$ & Masjid \\
$(005 \mathrm{c})$ & Masjid & $(019 \mathrm{a})$ & Gambar \\
$(005 \mathrm{~d})$ & Kerajaan & $(019 \mathrm{~b})$ & Alun-alun \\
$(006 \mathrm{c})$ & jid & $(020 \mathrm{~b})$ & Masjid \\
$(006 \mathrm{~d})$ & Rumah & $(029 \mathrm{a})$ & Sepeda \\
$(007 \mathrm{a})$ & Hotel & $(029 \mathrm{c})$ & Rumah \\
$(008 \mathrm{c})$ & Masjid & $(029 \mathrm{e})$ & Sekolah \\
$(009 \mathrm{a})$ & Pensil & & \\
\hline
\end{tabular}

Kata di atas menunjukkan nomina semantik, berarti kata tersebut mengacu padu manusia. Hasil penelitian menunjukan bahwa Syafiq termasuk anak berkebutuhan khusus yang didiagnosis autis ringan Menurut Childhood (Martina, 2014) kondisi anak autisme ringan masih menunjukan adanya kontak mata walaupun tidak berlangsung lama. Anak autis ini dapat memberikan sedikit respon ketika dipanggil namanya dan mampu berkomunikasi dua arah meskipun 
terjadinya hanya sesekali. Pemerolehan bahasa pada sintaksis Syafiq masih banyak yang harus diperbaiki dan proses berkomunikasi dengan Syafiq hanya bisa sebatas menjawab saja tanpa memberikan respon timbal balik dalam merespon pun perlu melakukan bimbingan. Syafiq juga selain tidak merespon sering melakukan berbicara sendiri atau membeo.

\section{SIMPULAN}

Berdasarkan hasil penelitian, dapat disimpulkan empat hal dalam pemerolehan bahasa sintaksis pada anak berkebutuhan khusus sebagai berikut. Pertama, pemerolehan kalimat tunggal pada Syafiq mampu menyebutkan pada kata subjek, predikat, objek, dan keterangan dan kalimat majemuk Syafiq sering muncul pada kalimat majemuk koordinatif tapi masih ada kata keliru yang diucapkan pada lawan bicara. Kedua, Pemerolehan klausa, Syafiq memperoleh aspek verba, nomina dan bilangan. Ketiga, pemerolehan frasa Pemerolehan frasa endosentrik Syafiq ini sudah banyak mengucapkan, namun kata frasanya langsung pada inti, sedangkan frasa eksosentrik terdapat beberapa frasa yang harus diperbaiki untuk dapat dimengerti oleh pendengar. Keempat, pemerolehan kata yang banyak diucapkan oleh Syafiq yaitu kata nomina (kata benda) mengacu pada manusia dan benda. Kata nomina ini termasuk kata-kata yang ada di lingkungan sekitar, jadi mudah diucapkan.

\section{DAFTAR PUSTAKA}

Anggraeni, L. A. V., Tirtayani, L. A., \& Sujana, I. W. (2019). Pengaruh Stimulasi Wicara dalam Pembelajaran Terhadap Kemampuan Berbahasa Anak Tunarungu Usia Dinidi TK Tunarungu Sushrusa. Jurnal Pendidikan Anak Usia Dini Undiksha, 7(2), 131-139.

Awalludin. (2017). Pengembangan Buku Teks Sintaksis Bahasa Indonesia (Penelitian dan Pengembangan terhadap Mahasiswa Program Studi Pendidikan Bahasa, Sastra Indonesia dan Daerah, Fakultas Keguruan dan Ilmu Pendidikan, Universitas Baturaja).

Chaer, A. (2009). Psikolinguistik Kajian Teoritik. Jakarta: Rineka Cipta.

Dardjowidjodjo, S. (2012). Psikolinguistik Pengantar Pemahaman Bahasa Manusia. Jakarta: Obor Indonesia.

Dardjowidjodjo, S. (2018). Echa Kisah Pemerolehan Bahasa Anak Indonesia. Jakarta: Grasindo.

Daroni, G. A. (2018). Pembelajaran Bahasa Indonesia untuk Anak Autis. INKLUSI: Journal of Disability Studies, V(2), 271-290.

Haliza, N., Kuntarto, E., \& Kusmana, A. (2020). Pemerolehan Bahasa Anak Berkebutuhan Khusus (Tunarungu) dalam Memahami Bahasa. Jurnal Genre (Bahasa, Sastra, dan Pembelajarannya), 2(1), 5-11.

Martina. (2014). Hambatan Berbahasa Anak Berkebutuhan Khusus di Bina Anak Bangsa Pontianak. Kandai, 10(1), 28-40.

Martina, Syam, C., \& Saman, S. (2014). Aktivitas Berbahasa Anak Berkebutuhan Khusus Pada Lembaga Pendidikan dan Pelatihan Bina Anak Bangsa Kota Pontianak. Jurnal Pendidikan dan Pembelajaran Khatulistiwa, 3(10), 1-14.

Mulyaningsih, I. (2015). Pemerolehan Bahasa Anak Pada Usia 4 Tahun dengan Whole Language. AWLADY: Jurnal Pendidikan Anak, 1(2), 1-13.

Moleong, L. J. (2007). Metodologi Penelitian Kualitatif. Bandung: Remaja Rosdakarya. 


\section{Indonesian Language Education and Literature e-ISSN: 2502-2261 \\ http://www.syekhnurjati.ac.id/jurnal/index.php/jeill/ \\ Vol. 6, No. 1, Desember 2020, 104 - 118}

Nurgiyantoro, B. (2005). Tahapan Perkembangan Anak dan Pemilihan Bacaan Sastra Anak. 2, 197-216.

Pandudinata, R., Sumarlam, S., \& Saddhono, K. (2018). Language Acquisition of Children with Mental Disabilities In Pacitan. Humanus: Jurnal Ilmu-Ilmu Humaniora, 17(1), 26-36.

Pujaningsih. (2010). Perkembangan Bahasa dan Gangguan Bahasa Pada Anak Berkebutuhan Khusus. JPK: Jurnal Pendidikan Khusus, 6(2), 42-53.

Ramlan, M. (2005). Ilmu Bahasa Indonesia: Sintaksis. Yogyakarta: C.V Karyono. Ratri, D. (2016). Psikologi Anak Berkebutuhan Khusus. Yogyakarta: Psikosain.

Sastra, G. (2011). Neurolinguistik: Suatu Pengantar. Bandung: Alfabeta.

Sugiyono. (2014). Metode Penelitian Kombinasi (Mixed Methods). Bandung: Alfabeta.

Sugiyono. (2016). Metode Penelitian Pendidikan Pendekatan Kuantitatif, Kualitatif, dan $R \& D$. Bandung: Alfabeta.

Suhardi. (2013). Pengantar Linguistik Umum. Yogyakarta: Ar-Ruzz Media.

Zahrina, L. N. (2016). Jurnal Pendidikan Bahasa dan Sastra Indonesia. Jurnal Pendidikan Bahasa dan Sastra Indonesia, 6(2), 44-59. https://doi.org/10.1007/s11010-011-1216-4. 